Dr RATOMIR MILIKIĆ, naučni saradnik

Institut za savremenu istoriju

Beograd, Trg Nikole Pašića 11

rasamilikic@gmail.com

originalan naučni rad

UDK 341.176(497.1)"1948/2003"

341.176(47)"1989/1991"

primljeno: 8. mart 2016.

327(497.1:47)"1998/1999"

prihvaćeno: 20. april 2016.

\title{
SRBIJA I RUSIJA U PARLAMENTARNOJ SKUPŠTINI SAVETA EVROPE NA KRAJU 20. VEKA*
}

APSTRAKT: $U$ članku se govori o odnosima Jugoslavije i SSSR/Rusije prema Savetu Evrope. Razmatraju se različiti odnosi obe zemlje sa ovom evropskom organizacijom tokom Hladnog rata. Promene koje su nastupile s perestrojkom dovele su do približavanja Moskve i Saveta Evrope, ali i do ubrzanog raspada SSSR-a. Ni Jugoslavija ni SSSR nikada nisu postali članovi te organizacije, već su to uradile države naslednice. Tokom agresije NATO na Jugoslaviju Parlamentarna skupština Saveta Evrope je većinom stala na stranu agresije, iako se veliki broj poslanika tome suprotstavljao. U tom otporu su, u skladu sa zvaničnom politikom Kremlja prema Srbiji, ali i sa ubedljivo preovlađujućim raspoloženjem javnosti u Rusiji, prednjačili poslanici ruske državne Dume. ${ }^{1}$

KLJUČNE REČI: Jugoslavija, Rusija, SSSR, Savet Evrope, kriza na Kosovu i Metohiji, multilateralna diplomatija

Savet Evrope je razgranata regionalna, panevropska organizacija, koja se proteže od Komiteta ministara (koji čine ministri ili njihovi stalni

"Rad je deo projekta Srpsko društvo u jugoslovenskoj državi u 20. veku: između demokratije i diktature (177016) koji finansira Ministarstvo prosvete, nauke i tehnološkog razvoja Republike Srbije.

${ }^{1}$ Članak je zasnovan na izvorima iz arhiva Saveta Evrope (Arhiv Parlamentarne skupštine Saveta Evrope, u daljem tekstu PSSE, arhiva predsednika PSSE, arhiva Komiteta ministara Saveta Evrope), Diplomatskog arhiva Ministarstva spoljnih poslova Republike Srbije (DA MSP), Arhiva Jugoslavije (AJ) (fond Kabinet Predsednika Republike - KPR, fond Predsedništvo SFRJ) i arhive Savezne skupštine. Tokom pisanja rada, dobili smo velikom ljubaznošću dr Konstantina Kosačova, predsednika Spoljnopolitičkog odbora ruskog Saveta Federacije i nekadašnjeg šefa Delegacije Rusije u PSSE i savetnika premijera Jevgenija Primakova, pet dokumenata od značaja za dalje produbljivanje ove teme. Oni predstavljaju stavove Rusije o Kosovu i Metohiji 1998-2000. godine. Od njih, samo jedan dokument ima delovodni broj, ali svi potiču iz arhiva MID (Ministarstva inostranih dela Ruske Federacije). Autor koristi i ovu priliku da zahvali Konstantinu Kosačovu na materijalima koje mu je stavio na uvid. 
predstavnici svih država članica), preko Parlamentarne skupštine, jedinstvene u svom sastavu u Evropi (nju sačinjavaju, po strogo utvrđenim pravilima, predstavnici parlamenata država članica i ona ima veoma širok spektar ovlašćenja, po čemu je posebna i razlikuje se od Evropskog parlamenta EU), Evropskog suda za ljudska prava, koji danas zasvođuje sistem evropskog pravosuđa, pa sve do usko stručnih tela poput Venecijanske komisije ili Farmakopeje.

Pošto su osnivačkim aktom iz Saveta Evrope bili izričito izuzeti bezbednosni aspekti (njima se bavio NATO, osnovan mesec dana pre Saveta Evrope), ova organizacija koja je nastala na početku Hladnog rata, usredsredila je svoje delovanje na oblast ljudskih prava i promociju demokratije. Zamišljen kao stožer oko koga je Evropa trebalo da se ujedini, zajedno sa (neostvarenom) Evropskom odbrambenom zajednicom (EOZ), Savet Evrope, a posebno njegova Parlamentarna skupština, vremenom je prerastao u debatni forum na najvišem nivou. Poslanici zemalja članica su u PSSE neretko zastupali lične ili partijske stavove, a ne državne, što je donosilo raznolikost mišljenja i često odstupanje od krutih diplomatskih normi.

Članak obuhvata dve vremenski različite, a tematski veoma spojene celine, odnos SSSR i SFRJ prema Savetu Evrope krajem Hladnog rata i odnos Ruske Federacije kroz Parlamentarnu skupštinu Saveta Evrope prema krizi na Kosovu i Metohiji (KiM).

Pošto je u januaru 1996. Rusija primljena u punopravno članstvo SE u toku unutrašnjeg sukoba koji je imala u Čečeniji, nameće se paralela sa po mnogo čemu sličnim sukobom na KiM, zbog koga je Srbija (tada još Savezna Republika Jugoslavija) bila izolovana i bilo joj je onemogućeno da pristupi Savetu Evrope.

Jugoslovenski odnosi sa Savetom Evrope mogu se pratiti još od 1948. godine (emigracija, Živko Topalović) a polovinom pedesetih godina uspostavljeni su i odnosi zvaničnog Beograda sa Strazburom. Predstavljena grafikonom ta linija krivuda, često praveći velike amplitude, ali ostaje neprekinuta sve do poslednje decenije XX veka. Tako je Jugoslavija došla najbliže od svih zemalja Istočne Evrope u proceduri pridruživanja Savetu Evrope posle pada Berlinskog zida, ali ju je građanski rat devedesetih za dugi niz godina odgurnuo od te panevropske organizacije. ${ }^{2}$

Spoljnu politiku jedne zemlje obično, shodno ustavu, kreira parlament, a predsednik i vlada tu politiku sprovode, u sadejstvu sa drugim državnim organima. To u slučaju Jugoslavije nije uvek bilo tako. Skupština jeste (vrlo formalno) odlučivala o spoljnopolitičkom kursu, ali je ona bila sve samo ne samostalna i slobodna u svojim odlukama.

${ }^{2}$ Arhiv PSSE, Yugoslavia - Historic Relations, 1969-1989, Memorandum, Points to be Raised with the Yugoslav delegation on 6 and 7 June 1977, 3 June 1977. 
Spoljna politika podrazumeva dva odvojena procesa: kreiranje spoljne politike kao politički proces i diplomatske aktivnosti u okviru kojih se ta politika sprovodi u delo. Ova dva procesa nisu nezavisni jedan od drugog, jer inicijativu za donošenje odluka često u praksi ima i diplomatska služba na čijem je čelu ministar inostranih poslova.

U slučaju Jugoslavije, predsednik Josip Broz Tito je (vaninstitucionalno) bio tvorac spoljnopolitičkog kursa zemlje u najbitnijim pravcima. Tako je lično kreirao stav prema SSSR-u i zemljama Istočnog bloka, kao i prema zapadnim silama. Po svemu sudeći i iskorak ka SAD i primanje obilate i za Jugoslaviju značajne pomoći, u periodu posle raskida sa SSSR-om i Staljinom 1948. godine, bili su njegova odluka.

Broz je bio nezaobilazan činilac u njenom kreiranju, ali kroz građu se može videti da za neke stvari nije bio ni preterano zainteresovan (pa je tada inicijativu prepuštao drugome, mada se sve uvek odvijalo uz njegovo znanje), ali i da se, istina u retkim slučajevima (i to pred kraj života) događalo da, suočen sa ubedljivom tuđom argumentacijom, promeni neki stav kada je reč o spoljnim poslovima. ${ }^{3}$

Najveća greška za istoričara bila bi da aršinima današnjeg vremena posmatra prošlost. Prilike koje su tada vladale i autokratski oblik državnog uređenja nametali su takvo rešenje u odlučivanju i kreiranju pravca spoljne politike.

Kada je reč o politici prema Parlamentarnoj skupštini Saveta Evrope, ona nije bila ni primarni, ni sekundarni prioritet Jugoslavije. Kao takva, ta politika mogla je da bude inicirana na terenu, kroz ličnost generalnog konzula Jugoslavije u Strazburu, koji je naišao na razumevanje u svojoj matičnoj kući. Sama ideja o popravljanju odnosa sa evropskim zemljama Zapada preko Saveta Evrope, dopala se saveznom sekretaru za inostrane poslove Koči Popoviću, a zatim i njegovom prethodniku na tom istom mestu, drugom čoveku (ili možda trećem) u jugoslovenskom državnom vrhu, Edvardu Kardelju. Pošto je u pitanju bio periferni front u spoljnoj politici Jugoslavije, Titu je delovala zanimljivo pomisao da se Jugoslavija možda može, posle samostalne diplomatske pobede zvane Balkanski pakt, ovenčati i članstvom $\mathrm{u}$ jednoj panevropskoj organizaciji koja se bavila promocijom demokratije. ${ }^{4}$

${ }^{3}$ Primer za to našli smo u materijalu sa sednice Predsedništva SFRJ povodom posete predsednika Tita Švedskoj 27. i 28. marta 1976. Arhiv Jugoslavije (AJ), fond 837, Kabinet Predsednika Republike (KPR), I-2/65.

${ }^{4}$ U domaćoj i stranoj literaturi ne postoji ozbiljnija studija koja se bavi problematikom odnosa između Jugoslavije i Saveta Evrope. U novije vreme jedina knjiga koja se dotiče odnosa Saveta Evrope i Jugoslavije jeste: Vladimir Đerić, Članstvo države u Savetu Evrope, Beogradski centar za ljudska prava, (Beograd: 2001). Takođe, D. Milić je 1960. objavio knjigu Evropski savet 1949-1959, a u biblioteci Instituta za međunarodnu politiku i privredu nalazi se nekoliko članaka koji se bave Savetom Evrope ili odnosom sa Jugoslavijom, ali su nam oni (uz sve nepreciznosti i činjenicu da su pisani u drugačijem okruženju i iz druge 
Iako možda na prvi pogled približavanje Savetu Evrope tokom 70-ih godina ima veze prvenstveno sa jugoslovenskom politikom prema KEBS-u, praćenjem daljeg sleda događaja može se uočiti da Jugoslavija Savet Evrope sad već vidi kao političku vizu za Evropsku ekonomsku zajednicu. ${ }^{5}$ Kroz proučavanje Saveta Evrope može se pratiti i evropska politika prema Jugoslaviji, kao i odnos Jugoslavije ka Evropi u ovom razdoblju, uz jasnu ogradu da se ne radi o spoljnopolitičkom prioritetu sve do kraja osamdesetih godina, a i od tada prevashodno zato što je Savet Evrope postao neka vrsta čistilišta za zemlje kandidate za prijem u Evropsku uniju (odnosno, prethodno, EEZ).

Nastavak saradnje koja će sada ponovo krenuti uzlaznom linijom teče $\mathrm{u}$ doba jačanja evropske dimenzije jugoslovenske spoljne politike $\mathrm{u}$ poslednjoj deceniji vladavine Josipa Broza Tita (1971-1980): Jugoslavija je tada počela da pristupa konvencijama Saveta Evrope. To je takođe bio presedan, koji je poslužio kao obrazac po kome su i zemlje iz komunističkog bloka mogle u narednim godinama da pristupe onim konvencijama Saveta Evrope koje su im odgovarale. Vrhunac sada već plodonosne saradnje sa Titovom Jugoslavijom predstavljala je poseta saveznog sekretara za inostrane poslove i potpredsednika SIV-a Miloša Minića koji se obratio Parlamentarnoj skupštini SE u januaru 1975. ${ }^{6}$ Nekoliko delegacija Savezne skupštine i Saveznog izvršnog veća 1977, 1978. i 1979. godine učestvovalo je u raspravama PSSE. Rečit primer vrlo srdačnih odnosa između Saveta Evrope i Jugoslavije može se naći u neuobičajeno prijateljskom i toplom telegramu saučešća upućenom jugoslovenskim zvaničnicima povodom katastrofalnog zemljotresa u Crnoj Gori 1979. godine. ${ }^{7}$

Jugoslavija je 1977. pristupila i ratifikovala tri obrazovne konvencije Saveta Evrope i dodatni protokol uz jednu od njih, da bi 1987. pristupila i Evropskoj kulturnoj konvenciji, kao 25. potpisnica, doduše posle nekoliko godina čekanja i pregovaranja sa zvaničnicima u SE, kao četvrta zemlja potpisnica koja nije u trenutku potpisivanja bila članica SE. ${ }^{8}$

perspektive) samo pomogli da potvrdimo već oformljene stavove. Posebno je bilo značajno da se uvidi vreme u kome su dela napisana, strogo se poklapajući (uz jedan izuzetak) s vremenom uzleta odnosa Jugoslavije i Saveta Evrope. Samo jedno od tih dela bavi se Parlamentarnom skupštinom Saveta Evrope, ali ni ono ne razmatra odnos sa Jugoslavijom. U pitanju su radovi koji mahom sadrže osnovne informacije o radu samog Saveta Evrope ili pojedinih njegovih organa, dok se oni malobrojni koji se dotiču odnosa sa Jugoslavijom pre svega bave mogućnostima budućih odnosa, a gotovo nimalo istorijatom tih odnosa.

${ }^{5}$ AJ, fond 837, KPR, I-2/64-4, Podsetnik o Portugaliji prilikom Titovog putovanja 20-22. marta 1976.

${ }^{6}$ Arhiv PSSE, Official Report of Debates, Vol III, Sittings 16 to 26, Strasbourg, 1975.

${ }^{7}$ Arhiva predsednika PSSE, telegram jugoslovenskim vlastima 1979. godine F(79) 10, 17. 4. 1979.

${ }^{8}$ Arhiv SE, La Yougoslavie, Vingt-Cinquieme etat signataire de la Convention Culturelle Europeenne. 
Pitanje pristupanja konvencijama Saveta Evrope bilo je važno kako za Jugoslaviju tako i za SE, jer nijedna zemlja iz Istočne Evrope do tada nije pristupila nijednoj od konvencija. Pojedine zemlje koje nisu članice Saveta Evrope - a neke od njih nisu ni geografski vezane za evropski prostor - jesu pristupale konvencijama SE, ali nijedna od njih nije bila komunistička (Izrael, Finska, Sveta stolica, Australija, Južna Afrika, Tunis, Kostarika). ${ }^{9}$

U vremenu urušavanja komunizma, pred pad Berlinskog zida, Jugoslaviju je već razjedala strukturna kriza. U poseti Beogradu 1988. godine boravio je i generalni sekretar KPSS Mihail Gorbačov koji je objašnjavao novu politiku Sovjetskog Saveza, perestrojku, polažući u nju velike nade. Ovdašnje rukovodstvo je formalno pozdravilo novi kurs, iako se jugoslovenski komunisti većinom nisu odlučivali na ozbiljnije reforme, zaokupljeni feudalnim borbama i uzajamnim optuživanjima. Zahtev za prijem u Savet Evrope SFRJ je podnela u poslednjoj celoj godini svog opstanka, 1990, da bi, smanjena i pod drugim imenom, bila primljena tek 2003.

SSSR je imao potpuno drugačiji put ka Savetu Evrope. Kao glavni ideološki suparnik, on i nije mnogo polagao na odnose sa Savetom Evrope sve do početka osamdesetih godina kada se može, mada prilično skromna po obimu, notirati tehnička saradnja na pojedinim poljima. Dolaskom Gorbačova menja se spoljna i unutrašnja politika SSSR-a i uočava se približavanje Moskve i Strazbura. Gorbačovljeva poseta Savetu Evrope poslužila je kao osnov novih odnosa. Tog 6. jula 1989. u Savetu Evrope se desilo nešto što je predstavljalo možda najveću prekretnicu u istoriji te organizacije: poslanicima Parlamentarne skupštine SE obratio se generalni sekretar Komunističke partije Sovjetskog Saveza koji je skicirao osnove novog kursa sovjetske politike i izneo svoju viziju jedne evropske kuće za sve. Bio je to predznak kraja Hladnog rata i nestanka bipolarnog sveta, bar na neko vreme.

Ni Moskva ni prestonice ostalih zemalja Istočnog bloka nisu više bile onakve kakve su bile početkom 80-ih godina. Perestrojka i glasnost su doprineli mnogo većem i prilično haotičnom otvaranju zemalja Istočnog bloka ka Zapadu. (To se posebno odrazilo na Mađarsku koja je takođe otpočela da razvija kontakte sa Savetom Evrope, ali i na druge zemlje poput Rumunije, koja je u poslednjoj godini Čaušeskuove vladavine, 1988, čak u nekoliko navrata ugostila zvaničnike SE. Promene su se očigledno nazirale, mada su dolazile mnogo brže nego što se bilo ko nadao kako na Istoku, tako i na Zapadu.)

U godini koju danas istoričari nazivaju prelomnom zbog pada Berlinskog zida, na samom početku nije ništa nagoveštavalo da će se tako brzo i naglo urušiti komunistička građevina i da, samim tim, sledi kratka i silovita završnica Hladnoga rata. Ta godina je i za Savet Evrope bila na neki

${ }^{9}$ Ibid. 
način istorijska, jer je 5. maja 1989. proslavljao svoj 40. rođendan, primivši u članstvo još jednu zemlju - Finsku, kao svoju 23. članicu.

U svečarskoj atmosferi, čelnici Parlamentarne skupštine Saveta Evrope donose međašnu odluku: za Jugoslaviju, Sovjetski Savez, Poljsku i Mađarsku biće uveden status specijalnog gosta, što je i učinjeno 11. maja 1989. Radilo se o velikoj novini za koju nije bilo formalne osnove ni u Statutu Saveta Evrope, ni u pravilima i poslovniku PSSE. Status specijalnog gosta u PSSE bio je prvi odgovor Saveta Evrope i Parlamentarne skupštine SE na događaje koji su se munjevitom brzinom dešavali u zemljama Centralne i Istočne Evrope.

Politika je o prvom nastupu delegacije jugoslovenske Savezne skupštine, kao i delegacija iz ostalih komunističkih zemalja, izveštavala iz Parlamentarne skupštine Saveta Evrope 26. septembra 1989. U tekstu svog dopisnika iz Francuske, Darka Ribnikara, Politika navodi da je „retko kada ... u toku minule četiri decenije neko zasedanje Parlamentarne skupštine Saveta Evrope posvećeno odnosima između Zapada i Istoka, proteklo u tako prijatnoj atmosferi, punoj optimizma“". ${ }^{10}$

„Prvi put (ako ne računamo svečanu sednicu ove skupštine u julu na kojoj je istupio Mihail Gorbačov), u klupama su se, sa svim pravima punopravnog člana osim glasanja o predloženim odlukama, našla i šestorica delegata Skupštine Jugoslavije, kao i predstavnici SSSR-a, Poljske i Mađarske, jer ove četiri države od juna ove godine uživaju status specijalnog gosta“.

Slovenija je 25. juna 1991. jednostrano proglasila nezavisnost. Dva dana kasnije jedinice JNA izašle su iz svojih kasarni u Sloveniji da bi vaspostavile red i mir, u sklopu zaštite ustavnog poretka i celovitosti SFRJ. Tom prilikom izbio je sukob sa teritorijalnom odbranom Slovenije i milicijom, što je dovelo do ljudskih žrtava na obe strane. Onesposobljena su sredstva veze i aerodrom u Ljubljani, dok civilni objekti nisu bili izloženi razaranju.

Na Vidovdan 1991. godine, Parlamentarna skupština Saveta Evrope je jednoglasno usvojila deklaraciju u kojoj se osuđuje svaka upotreba nasilja u Jugoslaviji, posle proglašenja nezavisnosti SR Slovenije i SR Hrvatske, i poziva na obostrano prihvatljive mirne pregovore pod pokroviteljstvom Evrope i OEBS-a.

Ubrzo zatim, PSSE je u septembru u Strazburu organizovala okrugli sto predstavnika saveznih vlasti i republika članica koji nije dao željene rezultate, osim što je neusaglašenost stavova bila povod da se zatraži formalno ukidanje Jugoslaviji statusa specijalnog gosta u PSSE, čime je faktički dat negativan odgovor na molbu za prijem Jugoslavije u punopravno članstvo u Savetu Evrope. ${ }^{11}$ Zahtev za ukidanje Jugoslaviji statusa specijalnog

\footnotetext{
${ }^{10}$ Полийика, 27. 9. 1989.

${ }^{11}$ Arhiv PSSE, Restricted, AS/Pol (43) 19, 4 November 1991.
} 
gosta u Parlamentarnoj skupštini SE u ime 15 poslanika PSSE podneo je ser Rasel Džonston. ${ }^{12}$

Time je prekinuta najdugovečnija saradnja Saveta Evrope sa nekom komunističkom zemljom, saradnja čiji su koreni sezali do polovine 50 -ih godina 20. veka. Ono što je usledilo bile su strahote najtežeg građanskog rata posle pada Berlinskog zida, dok je Savet Evrope $u$ isto vreme pronašao novi smisao svog postojanja kao dom znatno proširene evropske porodice država koje, bilo da su stare demokratije, bilo da su nove, tranzicione demokratije, dele iste vrednosti: poštovanje ljudskih prava i osnovnih sloboda i unapređenje demokratskog poretka. Jedino za ostatak Jugoslavije tu nije bilo mesta, jer dijaloga $u$ narednom periodu nije ni bilo.

Sovjetski Savez je imao potpuno drugačiji put ka članstvu u Savetu Evrope. I on se našao u vrlo nezavidnoj poziciji krajem 80-ih godina prošlog veka. Oslabljen Hladnim ratom, proživljavajući bolne ekonomske reforme i osećajući pukotine u Istočnom bloku, rešio je da otpočne saradnju sa najstarijom panevropskom organizacijom. Na tom putu nije bio sam: tu su se našle i pojedine komunističke zemlje Istočne Evrope, poput Mađarske, Rumunije i drugih.

Kada je Rusija u januaru 1996. primljena u Savet Evrope to je izazvalo najrazličitije reakcije u političkim krugovima niza zemalja evropskog kontinenta, čak i u samom Savetu Evrope. U Centralnoj i Istočnoj, kao i u Zapadnoj Evropi, bilo je glasova koji su tvrdili da ni Rusija ni Savet Evrope nisu spremni da $u$ potpunosti ispune obaveze koje nameće članstvo $u$ toj organizaciji. Tadašnji zamenik generalnog sekretara Saveta Evrope Peter Lojpreht, koji se najodlučnije zalagao za to da se novim kandidatima za prijem postave najstroži kriterijumi, čak je podneo ostavku.

O tome koliko je za samu Rusiju bio važan ulazak u Savet Evrope jasno svedoči i činjenica da od trenutka raspada Sovjetskog Saveza do podnošenja zahteva za prijem u tu organizaciju nije prošlo ni pola godine: već 7. maja 1992. Rusija je Strazburu dostavila zvaničan zahtev za prijem.

Rusija je apsolutno očekivala da bude primljena u Savet Evrope, shvatajući to kao protokolarno priznanje da je ona evropska država. ${ }^{13}$ Ona je od samog početka polazila od stanovišta da kao jedna od velikih evropskih

12 Arhiv PSSE, Sir Russel Johnston letter on 20 September 1991 (Rasel Džonston tada još nije dobio lordovsku titulu). Potpisnici zahteva bili su poslanici PSSE: Rasel Džonston, Oli Ren, Soares Kosta, Elizabet Arnold, Ištvan Sent-Ivanji, Šarl Gorens, Mirja Rinenen, Sirka-Lisa Atila, Jan Verbek, Irena Grendelmajer, Dik Des, Karolj Tot, lord Maki, Masimo Pini i Kornelija fon Tajhman.

13 Ушаков, Юрий Викторович, „39-й член Совета Европы“. Межgунарояная жизнь, № 3, (1996), 33. 
država ima prirodno pravo na članstvo u Savetu Evrope već zbog same svoje istorije, svog učešća u evropskom koncertu velikih država počev od 18. veka, svoje političke težine i autoriteta i proste činjenice da je izrazila želju da stupi u redove te organizacije. Ako se to ima na umu, onda nije teško shvatiti zašto su ruski politički krugovi kao krajnje nepovoljnu i uvredljivu doživeli komplikovanu proceduru prijema, skopčanu s mnogobrojnim uslovima. Kako je vreme odmicalo, tako su se zahtevi dodatno pooštravali, posebno pred kraj, zbog toga što se sama procedura prijema odvijala u vreme prvog čečenskog rata, koji je trajao od 1994. do 1996. Pravni eksperti Saveta Evrope kojima je bilo povereno da procene stanje ljudskih prava u Rusiji zaključili su, ne bez cinizma, da to stanje 1994. ne odgovara zahtevima Statuta SE i odredbama Evropske konvencije za zaštitu ljudskih prava i osnovnih sloboda. ${ }^{14}$

Moskvi su postavljena dodatna pitanja a odgovor na njih stigao je 20. januara 1995, upravo u vreme žestoke borbe za Grozni. Parlamentarna skupština SE suspendovala je 2. februara dalje razmatranje molbe Rusije za članstvo u Savetu Evrope. Ta suspenzija je, međutim, potrajala samo do juna 1995, kada je Parlamentarna skupština SE odlučila da ponovo otvori postupak prijema. Tako je Rusija 28. februara 1996. postala 39. član Saveta Evrope, ali je PSSE, uporedo sa odlukom o prijemu, formirala i specijalnu komisiju za praćenje razvoja događaja u Čečeniji. ${ }^{15} \mathrm{U}$ svakom slučaju, Rusija od samog početka nije imala jednak tretman sa ostalim članicama. Njen položaj je bio teži, njoj se svaki potez preduzet u krizi merio strožim merilima nego što su ona koja su važila za stare članice, Veliku Britaniju, na primer.

$\mathrm{Na}$ drugoj strani, od sredine 1997. izazov jugoslovenske spoljne politike bio je povratak u punopravno članstvo Ujedinjenih nacija gde je plaćala kotizaciju, imala ambasadora, ali nije imala pravo glasa zbog insistiranja na kontinuitetu sa bivšom SFRJ, zemljom osnivačem te organizacije. Slična je bila situacija i sa članstvom u OEBS-u, gde je isključenjem Jugoslavije početkom 90-ih godina prekršen i Statut te organizacije, koji izričito nalaže konsenzus svih država članica, a konsenzusa tom prilikom nije bilo. U kontekstu te inicijative, podneta je kandidatura za Savet Evrope u martu 1998. Ubrzo zatim, fokus jugoslovenske spoljne politike postala je odbrana

14 Ib Haurbi i Marta-Liza Magnuson, „Savet Evrope, Rusija i rat u Čečeniji“, http://www.caucasus. dk/rus/publicationrus1.htm (pristupljeno 27. 2. 2013).

${ }^{15}$ Prvi čečenski sukob završen je u avgustu 1996, posle potpisivanja sporazuma na osnovu kojeg su se ruske snage povukle, da bi u januaru 1997. Alan Mashadov, dotadašnji komandant čečenskih snaga, bio izabran za predsednika Čečenije na izborima koji su organizovani uz pomoć OEBS-a i koje su međunarodni posmatrači proglasili „slobodnim i fer izborima". 
državne celovitosti, posebno oličena u sporazumima Milošević-Holbruk iz oktobra 1998. i neuspešnim pregovorima u Rambujeu, tako da više nije bilo mesta za posvećivanje vremena i truda članstvu u Savetu Evrope.

Tokom leta 1998. godine i početkom jeseni ozbiljno se zaoštrila kriza na prostoru Kosova i Metohije. Kako se kriza zaoštravala, pojačavao se pritisak na jugoslovensko rukovodstvo da prihvati stranu asistenciju i posmatračku misiju, što je i dogovoreno posle teških pregovora 16. oktobra 1998. Taj sporazum su potpisali u ime Sjedinjenih Američkih Država specijalni izaslanik Ričard Holbruk ${ }^{16}$ i predsednik SR Jugoslavije Slobodan Milošević.

Već 17. oktobra 1998. pod okriljem OEBS-a imenovan je američki ambasador Vilijam Voker kao šef posmatračke misije, a za njegovog zamenika Gabrijel Keler, visoki francuski diplomata. Dana 25. oktobra 1998. misija je zvanično nazvana Kosovska verifikaciona misija i odlučeno je da u najkraćem roku bude raspoređena na terenu, a sve to u skladu sa Rezolucijom 1203 Saveta bezbednosti UN. ${ }^{17}$ Iako su bili raspoređeni po terenu, pripadnici Kosovske verifikacione misije mogli su samo da posvedoče o eskalaciji sukoba i aktivnosti ilegalne Oslobodilačke vojske Kosova (UČK), kao i pojačanju njihovog delovanja do te mere da su zauzimali pojedine gradove na teritoriji Kosova i Metohije kao Orahovac i neka druga, manja mesta. Na teritoriji Kosova i Metohije uvedeno je konstantno praćenje situacije na terenu i iz vazduha koje je ostalo na snazi, kao i svi zadaci Kosovske verifikacione misije, do druge polovine marta naredne, 1999. godine.

Godina 1999. u mnogo čemu je bila prekretnica ne samo za tadašnju Jugoslaviju, već i za međunarodnu zajednicu. Sistematskim vazdušnim napadima najveće svetske vojno-političke organizacije na jednu suverenu državu, makar ta država bila na udaru sankcija UN i makar njeno članstvo u UN bilo suspendovano, stvoren je dalekosežan i opasan presedan u posthladnoratovskom svetu. Takođe, koncept „humanitarne intervencije“ već u početku se pokazao toliko rastegljivim da se njime može pokriti svaka pogrešna procena, svejedno da li je plod smišljene obmane ili nesmotrenosti. Parlamentarna skupština Saveta Evrope, pod vođstvom novoizabranog

${ }^{16}$ Američki diplomata (1941-2010), demokrata po stranačkoj afilijaciji. Bio pomoćnik državnog sekretara za Aziju, potom za Evropu; ambasador SAD u UN i Nemačkoj. Po odlasku iz Stejt departmenta, u svojstvu privatnog građanina bio je izaslanik predsednika Klintona za Balkan. U administraciji Baraka Obame specijalni predstavnik za Avganistan i Pakistan. Jedan od najgorljivijih zagovornika širenja NATO, poznat po fleksibilnom tumačenju diplomatskih uzusa i često kontroverznim potezima, izuzetno energičan i ambiciozan. Pored diplomatije, pre svega njenog bezbednosnog aspekta, bavio se investicionim bankarstvom, prvo kao savetnik, potom kao izvršni direktor banke Liman braders koja je bankrotirala u septembru 2008.

${ }^{17}$ Arhiva predsednika PSSE, Non paper, Belgrade, 9. November 1998. 
predsednika lorda Rasela Džonstona, zdušno se priključila osudi SR Jugoslavije zbog dešavanja na prostoru Kosova i Metohije, ne trudeći se ni najmanje da pronikne u uzroke $\mathrm{i}$ istorijat krize.

Već samim početkom godine, od 4. januara nadalje, jugoslovenska diplomatija preko svog generalnog konzulata u Strazburu započinje diplomatsku kampanju promocije stavova zvaničnog Beograda. Generalni konzulat SRJ u Strazburu u prvoj depeši Savetu Evrope u 1999. godini ${ }^{18}$ daje jugoslovenski pogled na situaciju na Kosovu i Metohiji u opsežnom izveštaju koji pokriva period cele 1998. godine. U izveštaju se tipološki svrstavaju teroristički napadi, posebno obrađuju stradanja civila svih nacionalnosti, kao i pripadnika vojske i policije i pogranični incidenti, uz brojna druga kršenja ljudskih prava od strane albanskih terorista pod kapom UČK, a posebno nakon sporazuma Milošević-Holbruk iz oktobra 1998. Događaj koji je obeležio januar 1999. zbio se 15. tog meseca u malenom selu Račak na Kosovu i Metohiji. Tada su se jedinice MUP-a Republike Srbije u pokušaju da uhapse teroriste koji su ubili jednog policajca sukobile sa naoružanim albanskim teroristima. Tom prilikom bilo je više ranjenih pripadnika policije, kao i više poginulih pripadnika ilegalne UČK. Taj relativno uobičajen sukob, kakvih je bilo mnogo na KiM, lično je šef Verifikacione misije Vilijam Voker u odsustvu državnih organa Republike Srbije, i bez prisustva istražnih organa nadležnog suda u Prištini, novinarima koje je u tu svrhu okupio predstavio kao masakr nad nedužnim albanskim civilima. Iako su najviši srpski zvaničnici poput predsednika Republike Milana Milutinovića i drugih takve tvrdnje odmah demantovali, u svet je otišla slika i reč o navodnim srpskim zločinima na Kosovu i Metohiji. ${ }^{19}$

Mnogobrojne jugoslovenske izjave kako diplomatske, tako i u pisanim i elektronskim medijima nisu imale povoljan odjek u svetu. Zbog jako lošeg iskustva koje su imale, jugoslovenske vlasti su 18. januara uskratile gostoprimstvo Vilijamu Vokeru, proglasivši ga za personu non grata. ${ }^{20}$ Samo tri dana kasnije, 21. januara, savezna vlada je privremeno suspendovala uskraćivanje gostoprimstva Vokeru i on je na tom položaju ostao do samo nekoliko dana pred početak NATO bombardovanja SR Jugoslavije 24. marta 1999.

Kada je 24. marta uveče počela agresija, pojedini poslanici Saveta Evrope nisu sedeli skrštenih ruku. ${ }^{21}$ Već 25 . marta deset poslanika iz ruske

${ }^{18}$ Arhiva predsednika PSSE, Depeša Generalnog konzulata Jugoslavije u Strazburu broj 1/99, 4. januar 1999.

19 Arhiva predsednika PSSE, Consulat General de la Republique Federale le Yougoslavie lettre No 29/99, le 17 javier 1999.

${ }^{20}$ Arhiva predsednika PSSE, Letter by Živadin Jovanović on 18 January 1999.

${ }^{21}$ Arhiva predsednika PSSE, Communique by the Federal Government, 23 March 1999. 
delegacije je zatražilo da se po hitnoj proceduri ta tačka nađe na dnevnom redu Stalnog komiteta PSSE koji je trebalo da se održi 30. marta u Rimu.

Ruski poslanici, članovi nacionalne delegacije, govorili su u pet navrata tokom aprilske sesije PS Saveta Evrope. Ona je bila gotovo u potpunosti posvećena kosovskoj krizi. Zasedanje se odvijalo pod punom kontrolom lorda Rasela Džonstona, u izrazito antijugoslovenskom tonu. To je jedan od najočitijih primera u kojoj meri lični stavovi predsednika Parlamentarne skupštine mogu da utiču na diskusiju, bojeći je i dajući joj pravac: predsednik, između ostalog, može značajno da utiče na formiranje dnevnog reda, a, što se ovde pokazalo još važnijim, sam odlučuje o redosledu govornika. Glasovi neslaganja sa intervencijom, ma koliko uverljivi i pravno potkovani, tako su bili nadjačani. Najveći deo govornika koji su dobili reč na sednici odobravao je NATO bombardovanje Jugoslavije. Onih koji su osuđivali takav pristup rešavanju problema i ukazivali na brojne civilne žrtve i ogromna razaranja u Jugoslaviji nije bilo ni izdaleka toliko na spisku govornika, iako odnos snaga u sali nije bio tako izrazito u korist zagovornika oružane intervencije. Među onima koji su jasno i glasno osporavali pravo NATO da uređuje svet po svom nahođenju prednjačili su ruski poslanici. ${ }^{22}$

Stav Moskve prema agresiji na SR Jugoslaviju bio je izrazito negativan i čvrst, čak mnogo oštriji nego što su to objektivno dopuštali tadašnji izuzetno težak ekonomski položaj Rusije, previranja na unutrašnjoj sceni i kavkaska kriza. Taj stav je jasan i nedvosmislen u svim analiziranim dokumentima: Rusija odlučno osuđuje tu akciju koja krši Statut i Povelju UN i podriva osnove savremenog međunarodnog pravnog poretka, i traži da dejstva smesta budu prekinuta. U izjavi predsednika Rusije B. N. Jeljcina akcija NATO je okarakterisana kao neskrivena agresija.

U skladu s tom prvom predsednikovom izjavom ruski diplomatski predstavnici su zatražili hitno sazivanje sednice Saveta bezbednosti UN. Premijer Primakov je prekinuo put u Ameriku, u Moskvu je povučen glavni vojni predstavnik Ruske Federacije pri NATO, suspendovano je rusko učešće u programu Partnerstvo za mir i obustavljena realizacija programa partnerstva Rusije i NATO, a odloženi su i pregovori o otvaranju vojne misije NATO u Moskvi.

Na osnovu predsedničke izjave od 24. marta i Deklaracije Državne dume od 27. marta 1999. ruska strana je, osim već preduzetih koraka, donela odluku da se u Moskvi obustavi rad Dokumentacionog centra NATO za pitanja evropske bezbednosti. ${ }^{23}$ April 1999.

22 Official Report of Debates, Vol II, 1999 Ordinary Session (Second part) 26-30

${ }^{23}$ Saopštenje pres službe predsednika Ruske Federacije br. 1999-03-24-003. 
Na kraju se Moskva, preko svog predstavnika Viktora Černomirdina, uključila u pregovore i posle brojnih i, ako je suditi prema dostupnim dokumentima, u mnogome iscrpljujućih rasprava sa predstavnicima SAD i EU, bitno doprinela okončanju agresije na SR Jugoslaviju, kao i izglasavanju Rezolucije 1244 Saveta bezbednosti UN. Danas nema potrebe da objašnjavamo važnost te rezolucije za Srbiju. Savet Evrope, iako najaktivnije debatno parlamentarno telo, nije odigrao ključnu ulogu u završetku rata, ali su ga ruski poslanici, najviše što su mogli, iskoristili kako bi bar pokušali da utiču na stavove evropskih država, bez obzira na mnogobrojne probleme sa kojima se Rusija u to vreme suočavala i koji su joj, objektivno, otežavali međunarodni položaj i sužavali manevarski prostor.

Drugi čečenski rat izbio je 1. oktobra 1999. U januaru 2000. Čečenija je bila glavna tema na zasedanju PSSE (24-28. januar). Debata je vođena na osnovu izveštaja čiji je autor bio predsednik Skupštine lord Rasel Džonston. Parlamentarna skupština SE je osudila ruske vojne akcije kao „potpuno neprihvatljive“, ni ovde ne ulazeći, čak se ni ne trudeći da pronikne, u uzroke krize. Samo je ocenjeno da je Rusija „prekršila obaveze koje je preuzela potpisivanjem Evropske konvencije, odredbe međunarodnog humanitarnog prava i uslove pod kojima je primljena u Savet Evrope“. Bilo je i predloga da se ruska delegacija privremeno liši prava glasa. Oni su se ipak izjalovili. ${ }^{24}$

Tokom perioda Hladnog rata, jugoslovenski i sovjetski odnosi sa Savetom Evrope išli su različitim putevima. Jugoslavija je težila razvijanju odnosa, mada joj to nije spadalo u spoljnopolitičke prioritete. Savet Evrope je bio i osnovan kao odgovor na širenje „narodnih demokratija“ iza gvozdene zavese, tako da je saradnja sa SSSR-om bila malo verovatna. Promene koje su nastupile s perestrojkom dovele su do približavanja Moskve i Saveta Evrope, ali i do ubrzanog raspada SSSR-a. Ni Jugoslavija ni SSSR nikada nisu postali članovi te organizacije, već su to uradile države naslednice.

Sličnost sa Jugoslavijom se ogleda u činjenici da su tešnje veze sa Savetom Evrope nastupile u vreme „buđenja naroda" u obe države. Nastavši kao višenacionalne, često i bez potpune volje naroda koji su ih činile, obema državama istorija je beležila poslednje dane postojanja. Želja da

${ }^{24}$ Drugi čečenski sukob je bio odgovor Moskve na terorističke akcije radikalno nastrojenih čečenskih boraca, ovog puta Mashadovljevih protivnika. Na zasedanju Komiteta ministara Saveta Evrope održanom 4. novembra 1999. nije bilo govora o situaciji u Čečeniji, ali je istog dana Stalni komitet Parlamentarne skupštine doneo rezoluciju koja je pozivala na hitnu obustavu vojnih akcija i kršenja ljudskih prava. U januaru naredne godine to je bila glavna tema zasedanja PSSE. 
članstvom u Savetu Evrope osiguraju epitet poštovanja ljudskih i manjinskih prava, ma koliko i iskrena, došla je dockan.

Tokom agresije NATO na Jugoslaviju, Parlamentarna skupština Saveta Evrope je većinom stala na stranu agresije, iako se veliki broj poslanika tome suprotstavljao. U tom otporu su, u skladu sa zvaničnom politikom Kremlja prema Srbiji, ali i sa ubedljivo preovlađujućim raspoloženjem javnosti u Rusiji, prednjačili poslanici ruske Državne dume.

\section{IZVORI I LITERATURA}

- Arhiv Jugoslavije (AJ), fond 837, Kabinet Predsednika Republike; fond 803, Predsedništvo SFRJ

- Arhiva Komiteta ministara Saveta Evrope

- Arhiv Ministarstva inostranih dela Ruske Federacije

- Arhiv Parlamentarne skupštine Saveta Evrope (PSSE), Yugoslavia - Historic Relations, 1969-1989.

- Arhiva Savezne skupštine

- Diplomatski arhiv Ministarstva spoljnih poslova Republike Srbije (DA MSP), Politička arhiva (PA)

• Полийика (1989)

- Đerić, Vladimir. Članstvo države u Savetu Evrope, Beogradski centar za ljudska prava, Beograd: 2001.

- Ушаков, Юрий Викторович. „39-й член Совета Европы“. Межуународная жизнь, № 3, (1996), 33.

- Haurbi Ib, i Marta-Liza Magnuson. „Savet Evrope, Rusija i rat u Čečeniji“. http://www.caucasus. dk/rus/publicationrus1.htm (pristupljeno 27. 2. 2013)

Ratomir Milikić

\section{СЕРБИЯ И РОССИЯ В ПАРЛАМЕНТСКОЙ АССАМБЛЕЕ СОВЕТА ЕВРОПЫ В КОНЦЕ ХХ ВЕКА}

\section{Резюме}

В работе рассматриваются отношения между Югославией и $\mathrm{CCCP/Россией} \mathrm{к} \mathrm{Совету} \mathrm{Европы.} \mathrm{Во} \mathrm{время} \mathrm{„холодной} \mathrm{войны“} \mathrm{югославские} \mathrm{и}$ советские отношения с Советом Европы развивались различными путями. Югославия стремилась развивать отношения с Советом Европы, хотя это не 
входило в ее внешнеполитические приоритеты. При этом Совет Европы в свое время был создан как ответ на распространение „народныХ демократий“ за пределы железного занавеса, поэтому для развития сотрудничества с СССР было весьма немного возможностей. Перемены, пришедшие с перестройкой, привели к сближению Москвы и Совета Европы, но одновременно и к ускоренному распаду СССР. Ни СФРЮ, ни СССР никогда не стали странамичленами этой организации; членами стали их государства-правопреемники. В ходе агрессии НАТО в отношении Югославии Парламентская ассамблея Совета Европы большинством голосов проголосовала за агрессию, несмотря на то, что значительное число депутатов возражало против этого. В этом сопротивлении, в соответствии с официальной по-литикой Кремля в отношении Сербии, а также с преобладающим настроением российской общественности, особенно ярко выделялись депутаты российской Государственной Думы.

КЛЮЧЕВЫЕ СЛОВА: Югославия, Россия, СССР, Совет Европы, кризис в Косово и Метохии, мультилатеральная дипломатия

\section{SERBIA AND RUSSIA IN THE PARLIAMENTARY ASSEMBLY OF THE COUNCIL OF EUROPE AT THE END OF THE $20^{\text {th }}$ CENTURY}

\section{Summary}

The paper reviews relations between Yugoslavia and the USSR/Russia on one hand, and the Council of Europe (CoE) on the other. During the Cold War, the ties with the CoE were quite different for Yugoslavia and the Union of the Soviet Socialist Republics (USSR). Yugoslavia wanted to develop the relationship, even though it was not a foreign policy priority for the state. On the other hand, as the reason to create the Council was precisely to respond to the spread of "people's democracies" behind the Iron Curtain, cooperation with the USSR was quite an unlikely prospect. The changes introduced by perestroika brought Moscow and the CoE closer, but they also accelerated the disintegration of the USSR. Neither Yugoslavia nor the USSR ever joined the CoE; it was their successor states that did. During the NATO aggression against Yugoslavia, the Parliamentary Assembly of the Council of Europe (PACE) largely supported the aggression, opposition by a considerable number of PACE members notwithstanding. In line with Kremlin's official policy towards Serbia and the prevailing public sentiment at home, the most fervent opposition came from members of the Russian Duma.

KEYWORDS: Yugoslavia, Russia, USSR, Council of Europe, crisis in Kosovo and Metohija, multilateral diplomacy 